\title{
Development of the agricultural sector and its importance in Uzbekistan
}

\author{
Mansur Eshov ${ }^{1, *}$, Lochinbek Amirov $^{1}$, and Mavluda Askarova ${ }^{1}$ \\ ${ }^{1}$ Tashkent State University of Economics, 49 Islam Karimov Avenue, Tashkent, 100003, Uzbekistan
}

\begin{abstract}
The purpose of the study is to analyze the future prospective development of the agricultural sector of the Republic of Uzbekistan, in the context of the current pandemic. The study of this topic is of particular interest, since the pandemic around the world includes all spheres of the field of life. The pandemic negatively affected the development of the agricultural sector, which led to a recession. In this regard, the authors of this study tried to study the current state and consequences of the impact of the pandemic, and make appropriate recommendations. In the course of writing the work, the land rights of farmers, the food market, the level of modernization of agro-industrial production were studied. A theoretical method of analysis is used, data for the last 5 years, from 2015 to the present, are analyzed. The data characterizing the agrarian state of the Republic are grouped by regions and by branches of agriculture. With the help of deduction methods, proposals were made to improve the state of the agrarian sector. The study identified measures to further strengthen food security not only in the country, but throughout the world. The decisive factor should be the national agriculture strategy of the Republic of Uzbekistan for 2019-2030, which will contribute to the implementation of the proposed measures to ensure the well-being of the population.
\end{abstract}

\section{Introduction}

Science-based agrarian policy, which is an important condition for the alternative and effective development of the agro-industrial complex, is an integral part of state economic policy and one of the key factors in providing the population of the republic with food. In the coming years, the development of priority and new strategies of agrarian policy aimed at increasing the competitiveness of the agricultural sector and ensuring the social development of rural areas remains one of the pressing challenges.

The main issues of the country's agrarian policy in the coming years are to further improve the living conditions of the population, innovative approach to the development of the agrarian sector, increase the interest of rural labor, increase the competitiveness and efficiency of the agrarian sector in the domestic and world markets. active integration processes. The process of modernization and innovative development in our country necessitates a new approach to the restructuring of the agricultural sector - the development of new priorities in the development of agriculture. It is known from the world practice that

\footnotetext{
${ }^{*}$ Corresponding author: $\underline{\text { sb.i.1@mai.ru }}$
} 
the state plays a leading role in the implementation of the strategy of innovative development of the agricultural sector of the economy. In this case, the state will have to find the optimal alternative in cooperation with private business and reject the practice of excessive interference in business activities.

Modernization of the agro-industrial complex plays a key role in the agrarian policy of Uzbekistan. The inability to influence the volume of imports due to the lack of competitiveness of a significant part of agricultural production, in turn, increases the need for modernization. Modernization of the sector, which is a priority of Uzbekistan's agrarian policy, will ensure the transition to an innovative economy and increase its competitivenessp [1].

\section{Literature review}

In the current global pandemic, the level of agricultural development has become the cornerstone of countries 'development plans to ensure food security. Therefore, the development of the agricultural sector has both social and economic significance. A number of scientific literature and scientific articles on Internet sites, as well as other relevant literature, as well as data from the State Statistics Committee are important methodological sources in the preparation of this article.

"Agriculture in Uzbekistan is one of the most state-controlled sectors of the economy. The property rights of the largest agricultural producers, the farmers, are very poorly protected. The methods of regulating their activities are in fact from the Soviet past, many types of agricultural products, production resources and services for the sector have not been developed. The agricultural sector is in need of reform," economist Yuliy Yusupov told cabar.asia [2].

How to balance agricultural use, increase productivity and exports, and strengthen land rights, how to analyze the problems of agriculture in Uzbekistan, and answers to similar questions in the article of the World Bank's leading agricultural economist Sergiy Zorya given [3].

\section{Methods}

An expert analysis of the current pandemic development of the agricultural sector in Uzbekistan and food security around the world has been conducted. The network diagnostics were also conducted based on the results of the last 5 years in the field of the State Statistics Committee. During the current global pandemic, proposals and recommendations have been developed using deductive methods for the development of the agricultural sector in Uzbekistan.

\section{Results}

In order to increase the competitiveness of agricultural products in the world market, it is necessary to adopt a strategy for innovative development of the agricultural sector of Uzbekistan, based on world practices and principles, first of all, to increase the competitiveness of domestic agricultural products in the short term. 'ladi. The state plays a leading role in identifying and implementing priorities for the development of investment and innovation activities in agriculture in the modernization of the agricultural sector. Given the urgency of these issues, it will be necessary to develop targeted programs for the development of each individual sector of agriculture. Innovative programs include state financial and credit support, modernization of material and technical base, development of 
product processing, innovative development of production, increasing the importance of science, development of agro-industrial integration and improvement of the evaluation mechanism, direct -to encourage the production of certain types of products on the basis of proper procurement and include the effective implementation of the program.

These and other measures will allow the state to attract more local and foreign investment in the agro-industrial complex in the intensive development of agricultural production. The solution to the problems of the agricultural sector will largely depend on its financial condition. It is necessary to pay attention to the selection of the most effective alternatives to the restructuring, which will allow to apply external management measures to loss-making farms, to make full use of farm production funds and labor force and to adapt production to local conditions as much as possible. 'ladi. At the same time, it is important to have managers who are qualified and able to work effectively in market conditions. In order to determine this, the state certification of inter-sectoral heads of agriculture and the participation of scientists, industry leaders, as well as foreign experts and entrepreneurs in the certification process, along with representatives of the Ministry of Agriculture, will increase its effectiveness. does. The central part of any agrarian reform is, of course, the regulation of land relations. It provides for the rational use of land and its protection as a vital natural resource, the creation of conditions for its cultivation and productivity, as well as the development of equal market forms of land management. In the agricultural sector, it is necessary to create the most effective economic mechanisms for regulating land relations, which will lead to the rational use of land, taking into account the interests of the state and each farmer.

In order to make the measures more effective, it is advisable to establish research and development centers for strategic economic development in each administrative region with the involvement of scientists from different fields. The main tasks of the Agricultural Information and Consulting Centers will be to provide advice on economics, finance, taxation, pricing, and agricultural production in the first instance. In order to increase the efficiency and competitiveness of the agricultural sector of the economy, it is necessary to create a republican agro-industrial complex with an effective structure that provides interaction with the relevant ministry scientific institution, agricultural universities and agricultural advances. remains an issue. In this regard, a number of European countries have established information and consulting services, which play an important role in the development of the agricultural sector. The restructuring of Uzbekistan's agricultural sector must ultimately ensure the efficient operation of agricultural production and the radical social development of rural areas. To do this, it is necessary to re-adapt the population free from agricultural production, to further improve the social development of rural areas, longterm state programs, modernization of the structure of the rural economy. At the same time, the creation of non-agrarian alternative employment in rural areas remains an important issue in public policy, and the problems of small and medium business, trade, handicrafts, and the creation of ancillary industrial capacity in rural areas remain relevant.

The creation of a more sophisticated management structure of the agro-industrial complex is an important factor in the agrarian reform in the country. Its effectiveness depends on the work of government agencies. Regulating the economic, social, cultural and other problems of the villages is one of the main tasks of the governing bodies. For villages, which are an important factor in increasing the competitiveness of the agricultural sector, it will not be possible to conduct research on market problems and create effective management models in agriculture under market conditions without training highly qualified personnel.

The main direction of agricultural policy is to provide the population with quality products: 
- Comprehensive development of agro-industrial complexes, ensuring a comprehensive approach to all types of economic activities;

- development of measures to reduce the inflow of imported products and the cultivation of fully compensated agricultural products;

- Improving the quality of local agricultural products to meet world standards;

- protection of the interests of local producers;

- modernization of agro-industrial production, development and adoption of laws aimed at increasing the competitiveness of the industry, etc. are the leading factors in solving important problems of the national economy.

At present, the process of restructuring the agro-industrial complex should be carried out taking into account the integration of the industry into the world economy. In the context of globalization of the world economy, special attention should be paid to the development and regulation of agro-industrial foreign trade, the creation of a better mechanism to protect domestic producers from imports in the domestic market and, at the same time, create the necessary conditions for agricultural exports. is one of the most demanding issues.

In short, in the conditions of transition to the path of innovative development of agroindustrial complexes, its modernization requires the development and implementation of an improved strategy for the development of the agricultural sector. Its development requires the involvement of scientific potential, agricultural authorities, leading experts and leaders in the field, as well as foreign consultants.

\section{Discussion}

Agriculture, which accounts for 32\% of Uzbekistan's GDP and employs 27\% of the working population, could be one of the key factors in the country's economic growth under effective public policy. As a result of effective implementation of this policy, the volume of agricultural exports and incomes of farmers and agricultural organizations will increase, and thousands of new jobs will be created in rural areas. Living standards will rise, a number of food products will become cheaper for the population, and the country will be able to ensure reliable food security.

In 2018, 70\% of Uzbekistan's arable land was used for cotton and wheat. In recent years, some land has been excluded from cotton and wheat cultivation. However, in order to increase productivity in agricultural development, the additional land currently used for planting these two crops should be used later for other more useful crops, especially fruits and vegetables.

The World Bank estimates that reducing Uzbekistan's cotton and wheat acreage, for example by 50 percent, will increase agricultural output by 51 percent, agricultural employment by 16 percent, and water savings by 11 percent.

How soon should these lands be converted to more profitable crops? This process should be gradual and coordinated with changes in neighboring sectors. For example, the redistribution of land for growing fruits and vegetables should take place simultaneously with the improvement of agrologistics within the state and its customs borders. This, in turn, will ensure faster delivery of perishable fruits and vegetables from farmers to local consumers and the international market [5].

Otherwise, the profits from the processing of fruits and vegetables will be less than the profits from the sale of wheat and cotton.

The average yield of cotton, wheat, tomatoes, potatoes, milk and other products in Uzbekistan is much lower than their real potential [6]. Increasing this figure will not only increase the profits and exports of farms and agribusinesses, but also provide an 
opportunity to use the areas currently occupied by wheat and cotton for more profitable crops.

Table 1. Agricultural production by regions [4] (at current prices, billion soums).

\begin{tabular}{|l|l|l|l|l|l|l|}
\hline & 2015 & 2016 & 2017 & 2018 & 2019 & $\begin{array}{l}\text { January- } \\
\text { September } \\
2020\end{array}$ \\
\hline $\begin{array}{l}\text { The Republic } \\
\text { of Uzbekistan }\end{array}$ & 99604.6 & 115599.2 & 148199.3 & 187425.6 & 216283.1 & 173987.5 \\
\hline $\begin{array}{l}\text { The Republic } \\
\text { of } \\
\text { Karakalpakstan }\end{array}$ & 3332.2 & 3929.8 & 4801.3 & 6562.9 & 8208.1 & 5783.5 \\
\hline regions: & 9796.6 & 11873.4 & 15290.9 & 19606.3 & 23686.7 & 17663.5 \\
\hline Andijan & 8290.5 & 9812.2 & 12968.8 & 17064.6 & 19182.1 & 16277.8 \\
\hline Bukhara & 5685.3 & 6827.1 & 8835.0 & 11448.2 & 13720.1 & 10932.6 \\
\hline Jizzakh & 9089.0 & 10863.6 & 14360.6 & 17206.5 & 19933.9 & 17088.1 \\
\hline Kashkadarya & 4206.1 & 5034.7 & 6470.3 & 8299.8 & 9467.8 & 7988.3 \\
\hline Navoi & 6973.6 & 7973.7 & 10215.7 & 12639.6 & 15509.0 & 12260.2 \\
\hline Namangan & 14300.0 & 17088.6 & 21506.8 & 25658.0 & 28379.5 & 22443.0 \\
\hline Samarkand & 8218.0 & 8737.2 & 11608.1 & 15046.2 & 17844.1 & 13849.9 \\
\hline Surkhandarya & 3581.2 & 4088.4 & 5074.0 & 5654.3 & 7401.5 & 5708.1 \\
\hline Syrdarya & 10735.5 & 12034.2 & 15594.8 & 18359.1 & 20417.1 & 17347.3 \\
\hline Tashkent & 9180.9 & 9824.6 & 12388.0 & 17457.1 & 18532.2 & 15192.3 \\
\hline Fergana & 6215.7 & 7511.7 & 9085.0 & 12423.0 & 14001.0 & 11452.9 \\
\hline Khorezm & 1961 & & & & & \\
\hline
\end{tabular}

Issues such as the lack of funding for research and services over the decades and the lack of services needed to develop the sector need to be addressed. In 2018 , only $0.02 \%$ of Uzbekistan's gross agricultural output will be spent on agricultural research. However, at present, information and consulting services for local farmers are not available at all.

For comparison, middle-income countries with successful agriculture spend 1 percent of their gross agricultural output on agricultural research, while high-income countries spend an average of 2.5 percent.

In 2018, Uzbekistan's agro-food exports amounted to just \$ 1.3 billion, or \$ 330 per hectare of fertile land. By comparison, Vietnam exported $\$ 40$ billion worth of agricultural products that year. The state's export earnings are $\$ 6,100$ per hectare of productive land.

The government's economic reforms and measures to join the World Trade Organization will allow Uzbekistan to export agricultural products, especially fruits and vegetables, to many countries around the world $[7,8]$.

Another key issue for the country's agriculture is the need to ensure the full participation of labor resources in the implementation of export opportunities. Today, 60 percent of fruits and vegetables are grown on small farms and homesteads. However, their participation in the export-oriented production chain is still low.

Integration of agricultural cooperatives with these chains through government programs to encourage cooperation and cooperation of agricultural cooperatives with agribusiness 
and exporters would help to develop production capacity and increase the profitability of small farmers and private owners.

If the needs of farmers are not addressed, agricultural exports will only create new opportunities for small farmers and agro-organizational groups, and a great opportunity for inclusive economic development of this group of farmers will be missed. In 2018, public spending on agriculture in Uzbekistan amounted to 1.8\% of GDP (in 2016 and 2017 it was $2 \%$ of GDP).

Table 2. Growth rates of agricultural production by regions [4] (as a percentage of the previous year).

\begin{tabular}{|l|l|l|l|l|l|l|}
\hline & 2015 & 2016 г. & 2017 & 2018 & 2019 & $\begin{array}{l}\text { January- } \\
\text { September } \\
2020\end{array}$ \\
\hline $\begin{array}{l}\text { The Republic } \\
\text { of Uzbekistan }\end{array}$ & 106.1 & 106.3 & 101.0 & 100.2 & 103.3 & 103.4 \\
\hline $\begin{array}{l}\text { The Republic } \\
\text { of } \\
\text { Karakalpakstan }\end{array}$ & 109.8 & 108.3 & 103.1 & 100.6 & 107.0 & 101.5 \\
\hline regions: & \multicolumn{7}{|l|}{} & \multicolumn{1}{|l|}{} \\
\hline Andijan & 106.3 & 106.4 & 99.9 & 106.3 & 103.0 & 103.7 \\
\hline Bukhara & 107.1 & 108.4 & 103.5 & 102.9 & 103.6 & 103.0 \\
\hline Jizzakh & 106.7 & 106.3 & 103.5 & 99.7 & 106.4 & 104.3 \\
\hline Kashkadarya & 106.1 & 106.5 & 103.3 & 96.5 & 101.4 & 102.7 \\
\hline Navoi & 106.6 & 106.1 & 103.3 & 102.1 & 101.6 & 105.0 \\
\hline Namangan & 106.3 & 107.4 & 103.3 & 102.2 & 102.7 & 104.6 \\
\hline Samarkand & 107.1 & 108.4 & 100.4 & 94.1 & 103.1 & 100.6 \\
\hline Surkhondarya & 106.3 & 104.7 & 104.5 & 97.2 & 103.5 & 104.7 \\
\hline Syrdarya & 105.5 & 105.8 & 93.0 & 96.5 & 108.4 & 103.0 \\
\hline Tashkent & 103.3 & 101.9 & 96.9 & 98.8 & 101.1 & 104.2 \\
\hline Fergana & 105.7 & 105.7 & 97.1 & 109.7 & 103.5 & 103.9 \\
\hline Khorezm & 105.5 & 107.0 & 101.4 & 98.0 & 103.8 & 104.0 \\
\hline
\end{tabular}

Other countries allocate a relatively small share of GDP to agriculture. Middle-income countries spend an average of 0.6 percent of GDP, while high-income countries in the Organization for Economic Co-operation and Development (OECD) spend 0.2 percent of GDP. In 2018, Kazakhstan spent $0.8 \%$ of GDP on agriculture, while Vietnam spent $0.5 \%$. Even twenty years ago, when middle-income countries were poor, their agricultural budgets were 1.3 percent of GDP.

Despite high government spending, agriculture in Uzbekistan is still not very efficient. For example, in 2018, agriculture showed slightly above zero growth, and government funding for short- and medium-term agriculture needs to be increased to reduce budget expenditures for the development of a long-term sector. At the same time, it is necessary to focus on the efficiency of the use and use of budget funds.

For example, most of the budget is now spent on electricity, which is needed to irrigate the land, and on the management and operation of the irrigation system, which supplies water to cotton and wheat producers. At the same time, very little money is being spent on 
modernizing irrigation and land reclamation infrastructure. This means that in the short term, more government funding will be needed to modernize these infrastructures to serve the needs of diversified agriculture.[9]

In addition, many government programs that are critical to agricultural development have not always been fully funded. These programs include applied research in agriculture, dissemination of knowledge, education in agricultural sciences, soil fertility, food security, veterinary and phytosanitary services, business support (agricultural cooperatives, clusters, effective partnership relations), collection and analysis of statistical and market data, development of market infrastructure and agrologistics, environmental protection, policy analysis, training and monitoring of staff skills at any level. In the future, these programs may require large amounts of public funding.

The good news for Uzbekistan is that the country can quickly increase government spending efficiency by eliminating taxation of farmers due to lower government prices for wheat and cotton. Uzbekistan is one of the few countries in the world where domestic prices for basic agricultural products are lower than international standards. In many countries, the opposite is true. According to the World Bank, in 2018, Uzbek farmers lost 1.7 percent of GDP due to falling cotton and wheat prices. As a result, farmers are not encouraged to increase productivity:

Table 3. The main indicators of agriculture [4].

\begin{tabular}{|l|l|l|l|l|l|l|}
\hline & 2015 & 2016 & 2017 & 2018 & 2019 & $\begin{array}{l}\text { January- } \\
\text { September } \\
2020\end{array}$ \\
\hline $\begin{array}{l}\text { The area } \\
\text { under } \\
\text { agricultural } \\
\text { crops is one } \\
\text { thousand } \\
\text { hectares }\end{array}$ & 3694.2 & 3706.7 & 3474.5 & 3396.0 & 3309.4 & 3256.4 \\
\hline $\begin{array}{l}\text { Agricultural } \\
\text { production. } \\
\text { bln. soum }\end{array}$ & 99604.6 & 115599.2 & 148199.3 & 187425.6 & 216283.1 & 173987.5 \\
\hline including: & & & & & & 84249.7 \\
\hline farming & 55429.2 & 61755.1 & 83303.4 & 98406.4 & 111904.8 & 89737.8 \\
\hline $\begin{array}{l}\text { animal } \\
\text { husbandry }\end{array}$ & 44175.4 & 53844.1 & 64895.9 & 89019.2 & 104378.3 & 8 \\
\hline $\begin{array}{l}\text { Growth rate } \\
\text { of } \\
\text { agricultural } \\
\text { production in } \\
\text { percent to } \\
\text { last year }\end{array}$ & 106.1 & 106.3 & 101.0 & 100.2 & 103.3 & 103.4 \\
\hline including: & 105.5 & 105.7 & 98.2 & 95.8 & 104.8 & 104.3 \\
\hline farming & 106.9 & 107.0 & 104.1 & 105.7 & 101.6 & 102.3 \\
\hline $\begin{array}{l}\text { Animal } \\
\text { husbandry }\end{array}$ & 10.9 & & & & \\
\hline
\end{tabular}

The land tenure rights of small farmers are legally protected. This is one of the main reasons why small farmers pay more for material and technical resources, even though it is difficult to mechanize production on their small plots of land, and their productivity is higher than the average on large farms $[10,11]$.

However, for a number of reasons and at any time, large farmers may lose land leased from the state. This could be due to reorganization of farms, non-compliance with the crop 
placement plan, or non-compliance with the state plan for cotton and grain harvests, which are the responsibility of local authorities.

This outdated system of control over farm activities is catastrophically detrimental to their development, damaging farmers 'incentives to invest in land they have acquired for use by local governments. It is necessary to abandon this practice, which today serves the state against productivity [12].

The experience of China and Vietnam shows how to reform the approach to encouraging farmers. In these countries, the state procurement system has already been abolished, but this has not led to the collapse of agriculture. Here, the production of some strategic crops is stimulated by crop placement systems, direct budget payments to farmers and relevant government programs aimed at increasing productivity, improving product quality, as well as protecting them from pests and diseases [13,14]. This approach is different from the existing state cotton and wheat production support systems in Uzbekistan.

Unless farmers are fully convinced that their land rights are inviolable, they will not invest in improving labor productivity and improving the productivity of the land available to local authorities.

\section{Conclusions}

The following conclusions were drawn from the study:

- The land rights of farmers (small farmers) are legally protected;

- Many government programs that are critical to agricultural development have not always been fully funded;

- The main direction of agricultural policy is to provide the population with quality products;

- The main tasks of the agricultural information and consultation centers are to provide advice on economics, finance, taxation, pricing and cultivation of agricultural products in the first place.;

- Modernization of agro-industrial production, development and adoption of laws aimed at increasing the competitiveness of the industry are the leading factors in solving important problems of the national economy, etc.

As a result of the research, the following recommendations were developed:

- It is necessary to balance the use of agricultural land;

- maximum use of export potential for agricultural development;

- It is necessary to increase the efficiency of the use of budget funds to finance agriculture.;

- The right of farms to own land should be protected, etc.

Of course, the list of tasks and challenges listed above may seem quite extensive. However, their solutions are fully viable and are crucial for accelerating the modernization and competitiveness of agriculture, as well as for structural changes in the country's economy [15].

The National Agricultural Development Strategy for 2019-2030, which is currently being developed, should become a key document for the implementation of reforms in this area, which are ready to be supported by the World Bank and other international organizations. Its adoption and subsequent implementation by the government will directly implement the above-mentioned proposals and recommendations and turn them into economic opportunities for development and improvement of the well-being and living standards of the people of Uzbekistan [16]. 


\section{References}

1. B.S.Sultonov, A.O.Ruziev, Issues of priorities in the agricultural sector of Uzbekistan http://maqolalar.uz/gumanitar-soxa/siyosatshunoslik/1046-ozbekiston-agrar-sektorinirivojlantirish-ustuvor-yonalishi-masalalari.html

2. Agrarian sector of Uzbekistan: main problems, features, necessity of reforms https://kun.uz/uz/news/2019/03/30/ozbekiston-agrar-sektori-asosiy-muammolarxususiyatlar-islohotlar-zaruriyati

3. S. Zorya, Ways to make Uzbek agriculture more efficient and competitive https://www.gazeta.uz/oz/2019/07/08/agriculture/

4. www.stat.uz

5. Ş. Eryürük, B.I.S. Nesimioğlu, H.O. Altun, H. Açikgöz, S. Yumusąk, H.B. Yildiz, A. Cąlik, \& O.I. Ethem Bağriyanik, Research and Development Approaches and Implementation Issues in Agricultural Machinery Sector; Konya Case. Procedia Computer Science 158, 235-243 (2019) https://doi.org/10.1016/j.procs.2019.09.047

6. K. Fuglie, The growing role of the private sector in agricultural research and development world-wide, Global Food Security 10, 29-38 (2016) https://doi.org/10.1016/j.gfs.2016.07.005

7. S.S. Gharbia, A. Aish, T. Abushbak, G. Qishawi, I.Al. Shawa, A. Gharbia, M. Zelenakova, L. Gill, \& F. Pilla, Evaluation of wastewater post-treatment options for reuse purposes in the agricultural sector under rural development conditions, Journal of Water Process Engineering 9, 111-122 (2016) https://doi.org/10.1016/j.jwpe.2015.12.003

8. B. Mueller, \& C. Mueller, The political economy of the Brazilian model of agricultural development: Institutions versus sectoral policy, Quarterly Review of Economics and Finance 62, 12-20 (2016) https://doi.org/10.1016/j.qref.2016.07.012

9. L. Xiao, J. Liu, \& J. Ge, Dynamic game in agriculture and industry cross-sectoral water pollution governance in developing countries, Agricultural Water Management 243, 106417 (2021) https://doi.org/10.1016/j.agwat.2020.106417

10. S. Babu, et al. Food policy reforms in Central Asia: setting the research priorities, International Food Policy Research Institute Workshop Proceedings 22-65 (2000)

11. P. Bloch, Agrarian reform in Uzbekistan and other Central Asian countries, University of Wisconsin Land Tenure Center Working Papers 49, 4-18 (2002)

12. Z. Lerman, Land reform, farm structure, and agricultural performance in CIS countries, China Economic Review 20, 316-326 (2009)

13. Lerman, Z. (2008). Agricultural development in Uzbekistan: the effect of ongoing reforms. Center for Agricultural Economic Research Discussion Paper. No 7.08. 5-27.

14. Mundlak, Y. et al. (1997). Agricultural development: issues, evidence, and consequences. Policy Research Working Papers. 1811, 6-41

15. M. Spoor, Agrarian transition in former Soviet Central Asia: a comparative study of Kazakhstan, Kyrgyzstan and Uzbekistan, Working paper series 1928, 6-17 (1999)

16. G. Dustmurodov, I.O. Yunusov, U.K. Ahmedov, Sh.M. Murodov, S.T. Iskandarov, The mechanism for the development of public-private partnerships in agriculture (on the example of the Republic of Uzbekistan), E3S Web of Conferences 224, 04042 (2020) TPACEE-2020 https://doi.org/10.1051/e3sconf/202022404042 